\title{
Impacto do Tráfego Handoff no Sistema 3G UMTS/HSDPA Sob Vários Critérios de Aceitação e Escalonadores
}

\author{
Leandro Bento Sena Marques e Shusaburo Motoyama
}

\begin{abstract}
Resumo-Neste artigo é apresentado um estudo sobre o impacto do tráfego handoff HTTP no enlace direto do sistema UMTS/HSDPA. O estudo é baseado na introdução de novos critérios para a aceitação de tráfego handoff HTTP que leva em conta a potência do sinal recebido e o percentual de ocupação dos buffers. Além disso, o estudo considera os escalonadores de dados Max C/I (Maximum Carrier Interference), PF (Proportional Fair) e a nova proposta Pr/PF (Priority Proportional Fair). Os critérios combinados aos escalonadores são avaliados por meio de métricas de QoS em função da chegada de tráfego handoff. Os resultados mostraram que conforme o critério e escalonador adotados, podem assegurar a QoS do sistema HSDPA e ainda aceitar uma boa quantidade de tráfego handoff.
\end{abstract}

Palavras-Chave-sistema HSDPA, critérios de aceitação de tráfego handoff e o escalonador Pr/PF.

Abstract-In this paper is presented a study of HTTP handoff traffic impact in the forward link of UMTS/HSDPA system. This study is based on the introduction of new criteria for HTTP handoff traffic acceptance. These criteria are proposed considering the radio signal strength (RSS) and percentage of buffer occupation. Moreover, this study is carried out with acceptance criteria combined with data schedulers Max C/I (Maximum Carrier Interference), PF (Proportional Fair) and new proposal Pr/PF (Priority Proportional Fair). Different criteria and schedulers are evaluated through metrics of $\mathrm{QoS}$ in function of handoff traffic load. The results showed that depending on the chosen criterion and scheduler, it is possible to assure the QoS of HSDPA system and still to accept a good amount of handoff traffic.

Keywords-HSDPA system, handoff traffic acceptance and the Pr/PF scheduler.

\section{INTRODUÇÃO}

Os mecanismos de handoff são empregados nos sistemas celulares a fim de permitir a transferência de conexões das estações móveis (terminais) de uma estação rádio base (ERB) para uma outra ERB quando os terminais rompem ou aproximam-se dos limites da célula. Estes mecanismos asseguram mobilidade sem interrupção dos serviços. Basicamente, há dois tipos de handoff: soft handoff e hard handoff. No mecanismo soft handoff o terminal estabelece uma conexão com mais de uma ERB ao mesmo tempo a fim de assegurar uma transição mais suave entre as ERBs. No caso de hard handoff, o terminal encerra a conexão antiga antes de estabelecer uma nova em outra ERB.

Recentemente o grupo 3GPP (3rd Generation Partnership Project) padronizou uma nova interface aérea para o sistema

Leandro Bento Sena Marques e Shusaburo Motoyama, Venturus Centro de Inovação Tecnológica, Campinas-SP, Departamento de Telemática, Faculdade de Engenharia Elétrica e de Computação, Universidade Estadual de Campinas, Campinas-SP, E-mails: leandro.marques@venturus.org.br, motoyama@dt.fee.unicamp.br.
UMTS (Universal Mobile Telecommunication System) conhecida como HSDPA (High Speed Downlink Packet Access) [1]. Por meio desta nova interface o sistema UMTS/HSDPA provê altas taxas de dados de até $14,4 \mathrm{Mbps}$ no enlace direto (estação rádio base, ERB, para o terminal). Neste sistema adotou-se o mecanismo hard handoff uma vez que o soft handoff não é adequado a canais de alta de velocidade porque requerem mais códigos e causam interferências adicionais [10]-[11].

Os mecanismos de handoff tradicionais consideram a potência do sinal [9], a distância do usuário em relação à estação rádio base (ERB) e a relação SINR (Signal-toInterference-and-Noise-Ratio) para tomada de decisão no processo de handoff. Entretanto, devido a crescente demanda das aplicações sensíveis ao tempo os fatores anteriormente citados tornam-se insuficientes para a tomada de decisão num processo de handoff.

Desta forma, novos mecanismos de handoff têm sido propostos na literatura [11]-[13] na tentativa de aumentar a QoS das atuais e futuras gerações de redes móveis durante o handoff. Em [11] é proposto um modelo de fila no enlace direto de sistemas $4 \mathrm{G}$ em duas camadas. Na camada de rede são atribuídas prioridades aos fluxos handoff de acordo com seus respectivos estados no sistema. Na camada física é proposto um escalonador na qual considera a prioridade do fluxo, condição do canal e do buffer para a alocação de recursos. Os resultados deste estudo mostraram que a troca de informações entre as duas camadas permite um melhor gerenciamento dos recursos reduzindo o número de pacotes descartados no sistema.

Em um outro estudo apresentado em [12] é proposto o mecanismo de handoff QPPQ (Quality Prediction Priority Queuing) com base na taxa de pacotes recebidos com sucesso (PSR) para comunicações multimídia em redes sem fio. A tomada de decisão deste algoritmo baseia-se na atual PSR, taxa de degradação PSR e os requisitos mínimos de PSR para classe de serviço do pacote. Os resultados demonstraram que este mecanismo reduz a probabilidade de descarte de pacotes em comunicações multimídia. Entretanto, neste estudo o algoritmo handoff proposto é avaliado através de uma rede sem fio qualquer através de fontes poissonianas o que limita a aplicação prática dos resultados existentes neste artigo nas atuais redes de dados IP.

Por fim, no estudo [13] o mecanismo handoff no sistema HSDPA é analisado pelo modelo matemático de Stackelberg. Os resultados demonstraram que através deste modelo os recursos da rede foram utilizados com maior eficiência. En- 
tretanto, o artigo foca o modelo teórico em detrimento dos resultados práticos.

Neste artigo, são propostos dois novos critérios de aceitação de tráfego handoff que levam em conta a qualidade de serviço dos tráfegos. Além destes critérios é proposto o novo escalonador de dados Pr/PF a fim de garantir a QoS do sistema HSDPA durante o aumento de tráfego handoff presente no sistema. Nos critérios de aceitação de tráfego handoff os tráfegos são discriminados em classes de serviços e são tratados separadamente para satisfazerem a QoS individuais. A aceitação de tráfego handoff é baseada em potência do sinal e na ocupação do buffer e de forma a não degradar o tráfego interno de uma célula. Os critérios propostos são avaliados em conjunto com escalonadores Max C/I, PF e a nova proposta $\mathrm{Pr} / \mathrm{PF}$ que podem afetar o desempenho do sistema HSDPA.

O restante do artigo está organizado da seguinte forma: na Seção II são descritos alguns detalhes sobre o sistema UMTS/HSDPA. O modelo de simulação, os critérios para a aceitação de tráfego handoff e o escalonador Pr/PF são apresentados na Seção III. A Seção IV apresenta o cenário avaliado neste estudo. Na Seção V, são apresentados os resultados obtidos nas simulações e suas respectivas análises. Finalmente, na Seção VI são apresentadas as principais conclusões do estudo.

\section{SistemA UMTS/HSDPA}

A nova interface aérea HSDPA padronizada pelo grupo 3GPP é capaz de transmitir dados com taxas de até 14,4 Mbps no enlace direto em uma portadora de largura de banda de $5 \mathrm{MHz}$. Além desta interface foi proposto também pelo 3GPP no Release 6, o HSUPA [5] (High Speed Uplink Packet Access) para o enlace reverso (terminal para ERB). Nesta interface foram adicionadas novas melhorias no enlace reverso sendo possível a transmissão de dados com taxas de até 5,76 Mbps. Neste artigo foi adotado como objeto de estudo a interface aérea HSDPA referente ao enlace direto do sistema UMTS/HSDPA.

O HSDPA mantém a compatibilidade com o WCDMA[2] (Wideband CDMA) além de introduzir avanços significativos no sistema UMTS por meio de novas capacidades técnicas que quando combinadas oferecem aos seus usuários finais altas taxas de dados e baixas latências. Tais avanços são obtidos através dos mecanismos rápidos e complexos de controle de canais baseados em quadros de curta duração, modulação adaptativa, codificação dos canais, mecanismos de retransmissão como o ARQ híbrido (H-ARQ) e rápidos escalonadores de dados que possibilitam o aumento da eficiência do sistema UMTS/HSDPA [3].

Para facilitar a operação HSDPA três novos canais foram adicionados ao sistema UMTS. Estes canais são: o canal HSDSCH (High Speed Downlink Shared Channel), o canal HSSCCH (High Speed Shared Control Channel) e o canal HSDPCCH (High Speed Dedicated Physical Control Channel).

O canal do sistema UMTS/HSDPA HS-DSCH é partilhado com um SF (Spread Factor) de 16. Em cada TTI de $2 \mathrm{~ms}$, um SF fixo de 16 é usado com o máximo de 15 códigos paralelos no canal HS-DSCH. O número de códigos em uma célula HSDPA é configurado no Nó B. Estes códigos podem ser associados a um único usuário ou divididos entre vários usuários HSDPA [4]. Além disso, não há mais o controle de potência no HSDPA sendo o canal HS-DSCH transmitido numa potência constante com a modulação (16QAM, QPSK), codificação e o número de códigos variando conforme as condições do canal.

A alocação dinâmica dos recursos antes do começo de cada TTI é sinalizada para os usuários no novo canal de controle presente no enlace direto chamado de HS-SCCH. Através deste canal são informados: o esquema de modulação, a codificação e as informações relacionadas à retransmissão H-ARQ para cada usuário UE (User Equipment). Um único usuário pode monitorar até $4 \mathrm{HS}-\mathrm{SCCHs}$.

O canal HS-DPCCH é responsável por parte da sinalização do HSDPA com o envio de mensagens ACK, NACK e o CQI (Channel Quality Indicator). O CQI reflete a SIR (Signal to Interference Ratio) do canal. Com base no CQI, a ERB (Nó B) pode determinar a cada TTI os esquemas de modulação, a codificação e o número de códigos durante a comunicação [3]. A Figura 1 mostra de maneira simplificada os dados e as sinalizações trocadas durante a transmissão UMTS/HSDPA.

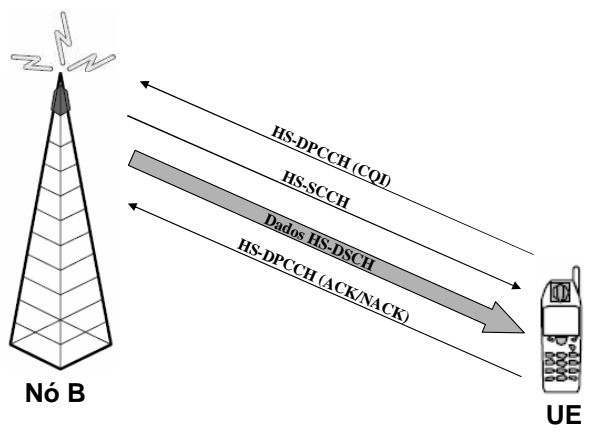

Fig. 1. Esquema de transmissão simplificado HSDPA

Em resumo, a Tabela I mostra as principais características do enlace direto do sistema UMTS/HSDPA conforme o 3GPP Release 5. Na coluna Inter TTI cada unidade equivale a $2 \mathrm{~ms}$.

TABELA I

TIPOS DE MODULAÇÃO POR TAXAS DE DADOS - ENLACE DIRETO HSDPA

\begin{tabular}{|c|c|c|c|c|c|}
\hline $\begin{array}{c}\text { Categoria } \\
\text { HS-DSCH }\end{array}$ & $\begin{array}{c}\text { Taxa } \\
\text { (Mbps) }\end{array}$ & $\begin{array}{c}\text { Bits por } \\
\text { Pacote }\end{array}$ & $\begin{array}{c}\text { Inter } \\
\text { TTI }\end{array}$ & Modulação & Código \\
\hline \hline Cat. 1 & $\mathbf{1 , 2}$ & 7300 & 3 & QPSK/16QAM & 5 \\
\hline Cat. 2 & $\mathbf{1 , 2}$ & 7300 & 3 & QPSK/16QAM & 5 \\
\hline Cat. 3 & $\mathbf{1 , 8}$ & 7300 & 2 & QPSK/16QAM & 5 \\
\hline Cat. 4 & $\mathbf{1 , 8}$ & 7300 & 2 & QPSK/16QAM & 5 \\
\hline Cat. 5 & $\mathbf{3 , 6}$ & 7300 & 1 & QPSK/16QAM & 5 \\
\hline Cat. 6 & $\mathbf{3 , 6}$ & 7300 & 1 & QPSK/16QAM & 5 \\
\hline Cat. 7 & $\mathbf{7 , 2}$ & 14600 & 1 & QPSK/16QAM & 10 \\
\hline Cat. 8 & $\mathbf{7 , 2}$ & 14600 & 1 & QPSK/16QAM & 10 \\
\hline Cat. 9 & $\mathbf{1 0 , 2}$ & 20432 & 1 & QPSK/16QAM & 15 \\
\hline Cat. 10 & $\mathbf{1 4 , 4}$ & 28776 & 1 & QPSK/16QAM & 15 \\
\hline Cat. 11 & $\mathbf{0 , 9}$ & 3650 & 2 & QPSK & 5 \\
\hline Cat. 12 & $\mathbf{1 , 8}$ & 7300 & 1 & QPSK & 5 \\
\hline \hline
\end{tabular}

\section{Modelo de Simulação}

Neste estudo, o desempenho do sistema HSDPA é avaliado durante o processo de handoff, isto é, além do tráfego interno da célula HSDPA são incorporados nesta célula tráfegos handoff provenientes de outras células vizinhas. A fim de assegurar a QoS do tráfego interno das células durante o processo handoff do sistema HSDPA são propostas estratégias para aceitação de tráfego handoff em conjunto com a escolha 
dos escalonadores de dados Max C/I, PF e a nova proposta $\mathrm{Pr} / \mathrm{PF}$.

\section{A. Modelo HSDPA}

O modelo handoff simplificado adotado neste estudo considera o impacto da entrada de tráfego handoff proveniente de várias ERBs, numa única ERB. Desta forma, um terminal que partiu de uma ERB qualquer em direção a ERB destino pode ser atendido de acordo com a distribuição de probabilidade da taxa de dados da Tabela II, isto é, dependendo da proximidade da ERB destino, da velocidade do terminal, da condição do canal naquele instante de tempo entre outros fatores.

Para representar o cenário exibido pela Figura 2, o tráfego total de chegada de pacotes $\lambda_{\text {total }}$ é dividido entre $\lambda_{h}$ e $\lambda_{i}$, ou seja, tráfego de chegada handoff e tráfego de chegada dos pacotes internos da célula respectivamente. O servidor HSDPA atende ao pacote conforme a Tabela I mediante a condição do canal no momento do atendimento do pacote. No sistema HSDPA com a aplicação da técnica TDM somente um pacote é atendido por vez com o máximo de potência. Além disso, neste modelo de sistema pode haver até quatro filas finitas de acordo com as prioridades atribuídas aos tráfegos que se pretende avaliar.

A parte em estudo do sistema HSDPA é mostrada na Figura 2a. Os pacotes gerados pela rede núcleo são enviados até o Nó B onde podem ser atendidos ou permanecer numa fila de espera enquanto aguardam o seu atendimento ou ainda serem descartados caso o buffer transborde. O servidor HSDPA segue um dos esquemas de escalonamento avaliados: Pr, PF ou Pr/PF. Os pacotes são atendidos, ou seja, transmitidos de acordo com a Tabela I e também conforme a condição do canal no momento do atendimento. O número de TTIs utilizados para transmitir um pacote varia de acordo com a taxa de dados. Além disso, neste modelo de sistema há várias filas finitas de acordo com o cenário avaliado. Assim, o modelo do enlace direto do sistema HSDPA é representado conforme a Figura $2 b$.

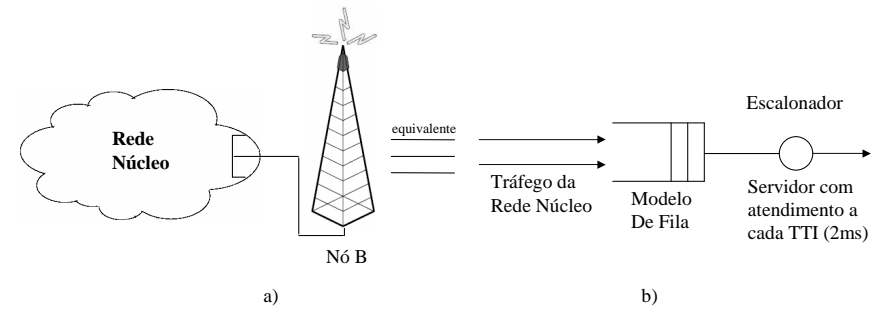

Fig. 2. Modelo HSDPA

As seguintes suposições são adotadas. Com o objetivo de obter uma melhor aproximação das atuais redes de dados são utilizadas fontes de tráfego HTTP. As fontes HTTP utilizadas neste estudo são as mesmas propostas em [6]. Em determinado momento são associadas prioridades aos pacotes antes de chegar ao escalonador. $\mathrm{O}$ escalonador baseia-se nos esquemas Max C/I, PF ou ainda Pr/PF. O buffer de cada fila tem tamanho finito e os pacotes HTTP são armazenados no esquema FIFO. Neste modelo handoff são desconsiderados o ruído e as interferências de outras células. $\mathrm{O}$ impacto da saída de tráfego handoff da célula HSDPA é desconsiderado devido ao maior fluxo de entrada de tráfego handoff.
As métricas de QoS avaliadas neste artigo são: o atraso médio dos pacotes e o percentual de perda de pacotes, todos em função da taxa de chegada de tráfego handoff. Para a simulação deste modelo foi utilizada a ferramenta de software Matlab.

As categorias de coberturas adotadas estão distribuídas conforme a estimativa mostrada na Tabela II. Os valores determinísticos, ou seja, fixos utilizados na distribuição de probabilidade da cobertura (PCobertura) não são dados reais, mas são apenas estimativas que consideram porcentagens de tráfegos maiores nas taxas intermediárias e porcentagens menores nas taxas altas ou baixas.

TABELA II

DisTRIBUIÇÃo DE PROBABILIDADE PELA TAXA DE DADOS

\begin{tabular}{|c|c|c|}
\hline \hline Categoria & Taxa (Mbps) & PCobertura \\
\hline \hline $\mathbf{1}$ & $\mathbf{1 , 2}$ & $3 \%$ \\
\hline $\mathbf{2}$ & $\mathbf{1 , 2}$ & $3 \%$ \\
\hline $\mathbf{3}$ & $\mathbf{1 , 8}$ & $4 \%$ \\
\hline $\mathbf{4}$ & $\mathbf{1 , 8}$ & $13 \%$ \\
\hline $\mathbf{5}$ & $\mathbf{3 , 6}$ & $12 \%$ \\
\hline $\mathbf{6}$ & $\mathbf{3 , 6}$ & $14 \%$ \\
\hline $\mathbf{7}$ & $\mathbf{7 , 2}$ & $18 \%$ \\
\hline $\mathbf{8}$ & $\mathbf{7 , 2}$ & $15 \%$ \\
\hline $\mathbf{9}$ & $\mathbf{1 0 , 2}$ & $8 \%$ \\
\hline $\mathbf{1 0}$ & $\mathbf{1 4 , 4}$ & $4 \%$ \\
\hline $\mathbf{1 1}$ & $\mathbf{0 , 9}$ & $2 \%$ \\
\hline $\mathbf{1 2}$ & $\mathbf{1 , 8}$ & $4 \%$ \\
\hline \hline
\end{tabular}

\section{B. Critérios de Aceitação de Tráfego Handoff}

Os novos critérios de aceitação de tráfego handoff visam atender aos estritos requisitos de QoS (baixos atrasos, jitter com variação reduzida e o pequeno percentual de perda de pacotes) das aplicações em tempo real. Desta forma, para promover a integração entre as células da maneira mais suave possível, estes critérios consideram além da potência do sinal recebido também o percentual de ocupação dos buffers como fatores determinantes para a tomada de decisão num processo de handoff.

1) Critério 1 de Aceitação de Tráfego Handoff: Neste critério 1 de aceitação, os pacotes são divididos em quatro tipos de prioridades e discriminados em diferentes buffers, um para cada prioridade. Esta divisão dos pacotes em quatro prioridades está em concordância com a arquitetura DiffServ, em que os usuários de serviços podem ser classificados de acordo com a qualidade de serviço (QoS) ouro, prata, bronze ou o melhor esforço. A distribuição de probabilidade das prioridades e o número máximo de posições disponíveis no buffer para cada prioridade são mostrados na Tabela III. Neste critério os pacotes internos da célula HSDPA somente são descartados quando o buffer estiver cheio. No caso dos pacotes handoff ocorre descarte nas situações em que o buffer esteja cheio ou quando o pacote handoff pertencer às categorias de cobertura inferiores 1, 2, 3 e 4 (vide Tabela II), isto é, as categorias que se caracterizam por apresentar sinais de baixa potência.

2) Critério 2 de Aceitação de Tráfego Handoff: No critério 2 de aceitação, a seguinte estratégia é usada: até 30\% de ocupação do buffer aceitam-se ambos os tráfegos interno e handoff, em outras palavras não ocorrem descarte de pacotes. Quando o nível de ocupação do buffer está entre $30 \%$ e $50 \%$ 
ocorre somente o descarte dos pacotes handoff no caso destes pacotes pertencerem às categorias de coberturas inferiores 1 , 2, 3 e 4 da célula HSDPA. Finalmente, na situação em que há mais de $50 \%$ de ocupação do buffer descartam-se ambos os pacotes em handoff e também os pacotes internos das células sem distinção. O principal objetivo deste critério é garantir QoS das conexões já em andamento.

\section{Escalonadores de Dados}

Nesta subseção são apresentados os escalonadores de dados adotados neste estudo tendo em vista que a padronização do sistema HSDPA não especifica os escalonadores a serem utilizados no gerenciamento de recursos do sistema. Assim, os seguintes escalonadores são avaliados: Max C/I (Maximum Carrier Interference) [8] e PF (Proportional Fair) [7] e Pr/PF (Priority Proportional Fair). Os dois primeiros escalonadores são bem conhecidos na literatura e o último escalonador está sendo proposto neste artigo.

1) Priority Proportional Fair (Pr/PF): O escalonador híbrido $\mathrm{Pr} / \mathrm{PF}$ proposto neste estudo combina o escalonador prioritário com PF. Neste esquema os pacotes com prioridades mais altas Pr1 (Prioridade 1) e Pr2 são atendidos primeiro enquanto os pacotes $\operatorname{Pr} 3$ e $\operatorname{Pr} 4$ são atendidos conforme o escalonador PF. Esta divisão dos pacotes em quatro prioridades está também em concordância com a arquitetura DiffServ. Desta forma, esta estratégia contempla os usuários que requerem melhores atendimentos e dispõem a pagar mais pelo serviço e também aqueles usuários com baixas restrições de QoS que toleram maiores atrasos durante a comunicação.

\section{Cenário Avaliado}

O cenário apresentado neste estudo avalia o desempenho do sistema HSDPA durante o processo de handoff através de novos critérios para aceitação de tráfego handoff. Além disso, estes critérios são avaliados em conjunto com os escalonadores de dados Max C/I, PF e o novo escalonador proposto neste estudo Pr/PF.

A distribuição de probabilidade das prioridades adotadas neste estudo são apenas estimativas baseadas em proporções maiores para os tráfegos de baixa prioridade e em proporções menores para os tráfegos de alta prioridade. Além da distribuição de probabilidade das prioridades, a Tabela III exibe os tamanhos dos buffers para cada tipo de prioridade. Outro objetivo deste trabalho é avaliar o impacto da variação do tamanho do buffer no desempenho do sistema HSDPA. Desta forma, dois tamanhos de buffers são considerados para cada prioridade.

TABELA III

DistribuiçÃo DE PRIORIDAdES X TAMANHO DOS Buffers

\begin{tabular}{|c|c|c|c|}
\hline \hline Prioridade & Proporção & Buffer1 & Buffer2 \\
\hline \hline 1 & $10 \%$ & 1 & 10 \\
\hline 2 & $25 \%$ & 3 & 25 \\
\hline 3 & $30 \%$ & 3 & 30 \\
\hline 4 & $35 \%$ & 3 & 35 \\
\hline \hline Total & $100 \%$ & 10 & 100 \\
\hline \hline
\end{tabular}

O cenário em estudo consiste em manter fixo o número de fontes internas HTTP (26 unidades) da célula HSDPA e aumentar o número de fontes HTTP handoff de 0 até 174 fontes. Este cenário avalia a combinação dos novos critérios de aceitação de tráfego handoff juntamente com a escolha do escalonador de dados com o objetivo de assegurar a QoS no sistema HSDPA. A Tabela IV mostra o cenário avaliado. Nesta tabela, por exemplo, no cenário em que há um total de 73 fontes HTTP, 47 delas, ou seja, 64\% do total pertencem ao tráfego HTTP handoff enquanto as outras 26 fontes representam os outros $36 \%$ do tráfego HTTP interno da célula.

TABELA IV

Cenário Avaliado

CENÁRIO AVALIADO
\begin{tabular}{|c|c|c|c|c|c|}
\hline \hline Percentual de Tráfego Interno & $100 \%$ & $74 \%$ & $36 \%$ & $22 \%$ & $13 \%$ \\
\hline Percentual de Tráfego Handoff & $0 \%$ & $26 \%$ & $64 \%$ & $78 \%$ & $87 \%$ \\
\hline Fontes HTTP Internas & 26 & 26 & 26 & 26 & 26 \\
\hline Fontes HTTP Handoff & 0 & 9 & 47 & 92 & 174 \\
\hline \hline Total de Fontes HTTP & 26 & 35 & 73 & 118 & 200 \\
\hline \hline
\end{tabular}

\section{ANÁlise dos RESUltados}

Nesta seção são apresentados os resultados das simulações do sistema HSDPA. Os diferentes critérios para aceitação de tráfego handoff estão identificados pelas siglas Pot e PotOcp. A sigla Pot representada nos gráficos pelas linhas tracejadas refere-se ao critério 1 na qual se leva em conta a potência do sinal recebido. A outra sigla PotOcp representada pelas linhas contínuas nos gráficos faz referência ao critério 2 na qual são consideradas a potência do sinal recebido e a ocupação dos buffers na tentativa de assegurar a melhor QoS no processo de handoff do sistema HSDPA. As simulações computacionais apresentam em geral um desvio padrão de $6,52 \%$ do valor da média enquanto o intervalo de confiança de $95 \%$ apresenta $4,04 \%$ do valor da média.

Além das siglas que identificam os critérios para a aceitação de tráfego handoff são utilizadas as siglas MXCI, PF e $\mathrm{Pr} / \mathrm{PF}$ representando, respectivamente, os escalonadores de dados Maximum Carrier Interference, Proportional Fair e Priority Proportional Fair. Por fim, os números nos finais das siglas que identificam os escalonadores de dados, associam prioridades a cada tipo de tráfego variando de 1 a 4 , isto é, da prioridade mais alta para prioridade mais baixa.

O atraso médio dos pacotes HTTP internos no sistema HSDPA com prioridade 1 para a condição de buffer 1 é mostrado na Figura 3. O critério de aceitação de tráfego handoff PotOcp apresenta maiores atrasos ao longo da simulação em virtude do maior número de pacotes internos e em handoff presentes no sistema. Ao contrário do critério PotOcp, o critério Pot obtém atrasos menores devido ao elevado descarte de pacotes handoff. Os menores atrasos durante a simulação são conferidos ao escalonador Pr/PF em que é dada a prioridade absoluta ao usuário de prioridade mais alta, variando de $0,8 \mathrm{~ms}$ até 3 ms. O escalonador de dados Max C/I apresenta desempenho intermediário com atrasos entre $1 \mathrm{~ms}$ e $6,2 \mathrm{~ms}$, conseqüência direta da escolha do escalonador por usuários com as maiores taxas de dados. Por fim, o escalonador PF1 possui o pior desempenho quando comparado aos outros escalonadores de dados com os atrasos variando de $1,1 \mathrm{~ms}$ a $10,1 \mathrm{~ms}$.

Na Figura 4 avalia-se o atraso médio dos pacotes HTTP internos Pr1 do sistema HSDPA, porém com o buffer 2, a fim de verificar o impacto do tamanho dos buffers no desempenho 


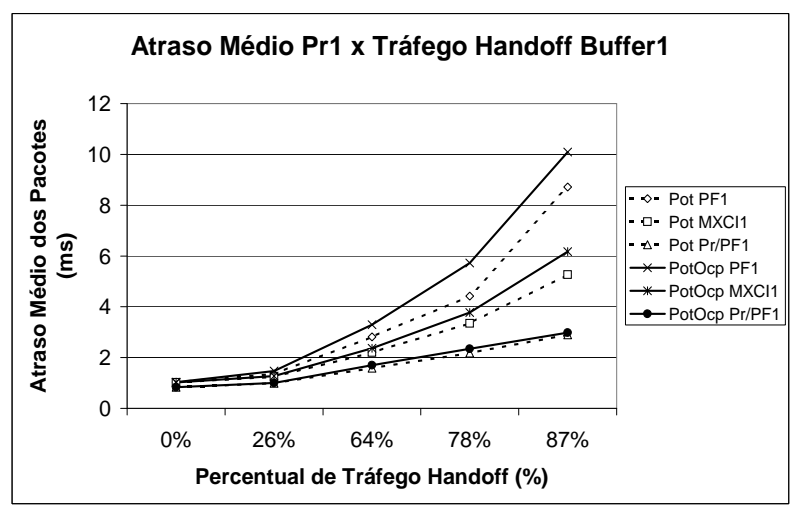

Fig. 3. Atraso Médio do Tráfego Interno de Pacotes de Prioridade 1 no Buffer 1 da Célula HSDPA

do sistema. O comportamento das curvas de dados é semelhante ao da Figura 3. Contudo, em razão do aumento do buffer de 10 para 100 posições, os atrasos verificados são maiores do que na figura anterior devido ao maior número de pacotes presentes no sistema. Por exemplo, para o esquema PotOcp PF1 o atraso varia de $0,9 \mathrm{~ms}$ a $22,6 \mathrm{~ms}$, ou seja, o atraso é 2 vezes maior do que PotOcp PF1 com buffer 1. A exceção é o escalonador de dados Pr/PF1 em que o atraso observado é muito próximo do obtido na Figura 3, variando de $0,89 \mathrm{~ms}$ a 3,4 ms devido à prioridade absoluta associada ao usuário de prioridade 1 . Nota-se que mesmo aumentando-se o número de posições no buffer em dez vezes em relação ao buffer 1 , o escalonador Pr/PF manteve a eficiência no atendimento dos pacotes internos de Pr1 da célula HSDPA.

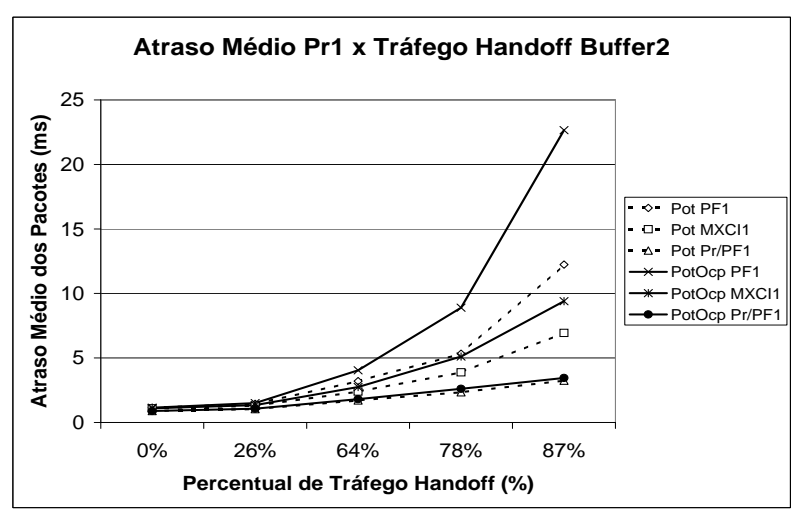

Fig. 4. Atraso Médio do Tráfego Interno de Pacotes de Prioridade 1 no Buffer 2 da Célula HSDPA

A Figura 5 exibe o atraso médio dos pacotes HTTP internos no sistema HSDPA com prioridade 4 para a condição de buffer 2. Novamente, o critério PotOcp apresenta os maiores atrasos durante a simulação devido ao maior número de pacotes handoff presentes no sistema. Por outro lado, o critério Pot obtém os menores atrasos ao custo de perdas significativas de pacotes handoff. Nesta figura, salienta-se a inversão ocorrida nos desempenhos dos escalonadores Pr/PF e PF devido aos usuários de baixa prioridade. Para estes usuários, o escalonador PF4 garante os menores atrasos, independente do critério de aceitação, com atrasos inferiores a 48,6 ms no pior caso. Este desempenho está atrelado a melhor distribuição de recursos do sistema HSDPA provido por este escalonador na qual beneficia usuários de baixa prioridade. Além disso, destaca-se também a tendência negativa em termos de desempenho do escalonador Max C/I ao apresentar elevados atrasos a partir do percentual handoff de $78 \%$. Este comportamento resulta do favorecimento dos usuários em melhores condições de canal e da penalização dos usuários em piores condições de canal, mais distantes do Nó B.

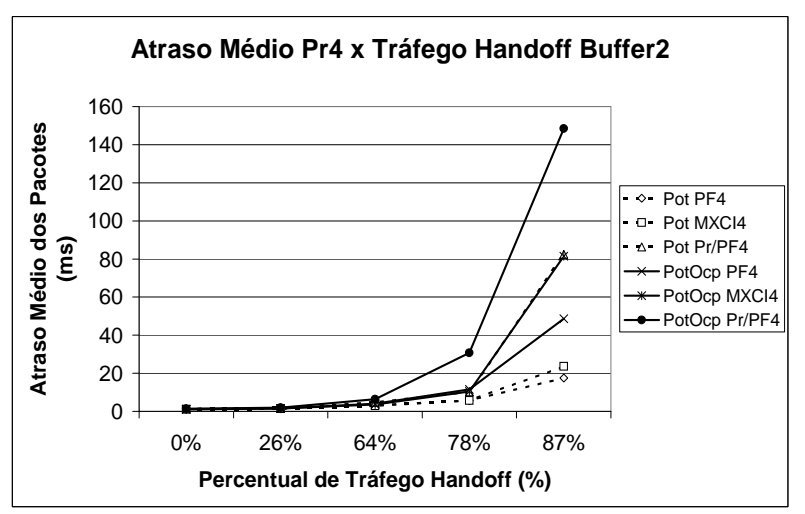

Fig. 5. Atraso Médio do Tráfego Interno de Pacotes de Prioridade 4 no Buffer 2 da Célula HSDPA

A Figura 6 mostra o percentual de perda de pacotes de prioridade 1 do tráfego HTTP interno para o buffer 1 no sistema HSDPA. Os maiores percentuais de perdas de pacotes internos nesta figura são atribuídos ao critério PotOcp devido ao descarte de pacotes internos quando a ocupação do buffer 1 é superior a 50\%. Por outro lado, o critério Pot somente descarta os pacotes internos quando o buffer 1 transborda o que garante os menores índices de descarte. Além disso, observase o melhor desempenho do escalonador Pr/PF1 comparados aos outros escalonadores MXCI1 e PF1 uma vez que este escalonador garante atendimento diferenciado aos usuários de alta prioridade.

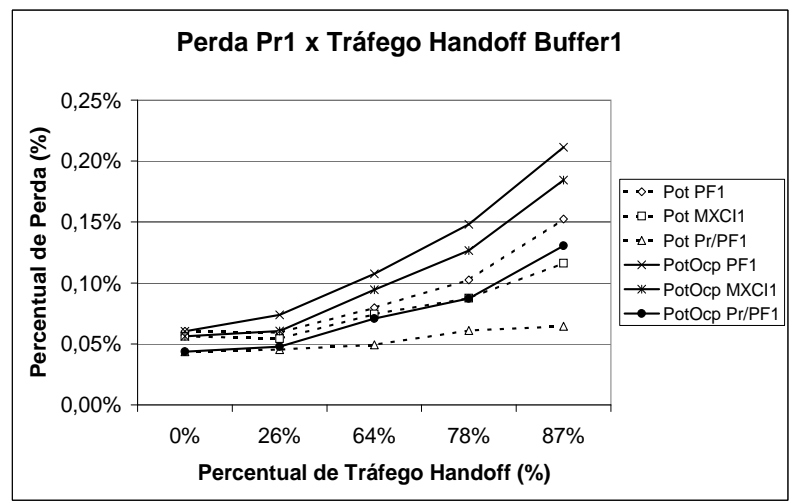

Fig. 6. Percentual de Perda do Tráfego Interno de Pacotes de Prioridade 1 no Buffer 1 da Célula HSDPA

A Figura 7 mostra o percentual de perda de pacotes de prioridade 4 do tráfego HTTP interno para o buffer 1 no sistema HSDPA. O critério Pot, baseado na potência do sinal recebido, apresenta os menores percentuais de descarte na simulação quando comparados aos seus equivalentes do critério PotOcp. Estes comportamentos refletem as políticas de aceitação de tráfego handoff destes critérios, uma vez que no critério PotOcp para uma ocupação maior que $50 \%$ do buffer ocorre o descarte de pacotes HTTP internos, enquanto no critério Pot somente ocorre o descarte de pacotes HTTP internos quando o buffer estiver cheio. Por outro lado, apesar do critério Pot beneficiar o tráfego HTTP interno com baixo índice de descarte de pacotes ele acaba por penalizar o tráfego 
HTTP handoff com altos índices de descarte. Além disso, quando combinado o escalonador de dados PF4 com o critério Pot, obtém-se o menor percentual de descarte de pacotes de prioridade 4 variando de $0,001 \%$ até o máximo de $0,2 \%$ durante a variação do percentual de tráfego handoff.

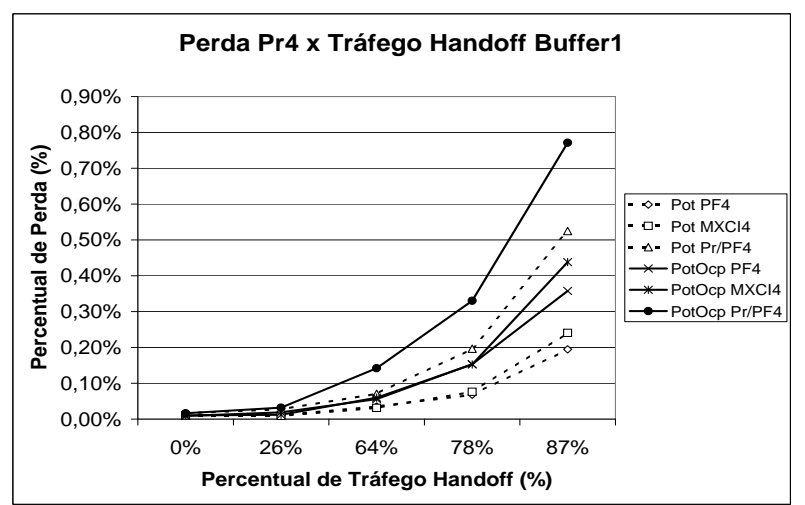

Fig. 7. Percentual de Perda do Tráfego Interno de Pacotes de Prioridade 4 no Buffer 1 da Célula HSDPA

Por fim, na Figura 8 é mostrado o percentual de perda de pacotes de prioridade 4 do tráfego HTTP handoff, para o buffer 2 no sistema HSDPA. Nesta figura notam-se os altos índices de descarte de pacotes HTTP handoff, uma vez que na concepção dos critérios de aceitação de tráfego handoff nas células HSDPA, priorizou-se o tráfego HTTP interno das células. Desta forma, devido o critério Pot descartar pacotes handoff das categorias de cobertura inferiores 1, 2, 3 e 4 impôs como consequiência altos percentuais de descarte comparados ao PotOcp com taxas de até 7,6\% para o Pot Pr/PF4. Por outro lado, o critério PotOcp garante uma redução de mínimo $50 \%$ do percentual de perda de pacotes HTTP handoff no pior caso na comparação com o critério Pot conforme se aumenta o percentual de tráfego handoff. Do ponto de vista dos escalonadores de dados, o escalonador PF4 garante os menores índices de descarte de pacotes handoff ao longo da simulação para ambos os critérios de aceitação de tráfego handoff.

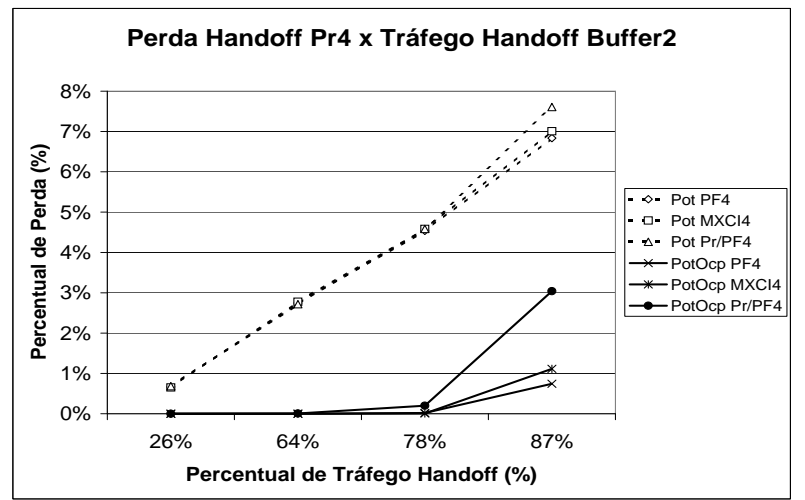

Fig. 8. Percentual de Perda do Tráfego Handoff de Pacotes de Prioridade 4 no Buffer 2 da Célula HSDPA

\section{CONCLUSÕES}

Neste artigo, foram propostos e avaliados critérios de aceitação tráfego handoff em conjunto com os escalonadores de dados PF, Max C/I e a nova proposta Pr/PF, no intuito de assegurar a QoS do tráfego interno da célula e minimizar a degradação de desempenho causado pelo aumento de tráfego handoff no sistema móvel HSDPA. Os impactos destes critérios de aceitação de tráfego handoff juntamente com a escolha dos escalonadores de dados PF, Max C/I e $\mathrm{Pr} / \mathrm{PF}$ foram avaliados através de simulações computacionais feitas na ferramenta de software Matlab. O atraso médio e o percentual de perda dos pacotes foram estudados em função da taxa de chegada de pacotes handoff.

O critério de aceitação de tráfego Pot apresentou, em geral, o melhor desempenho nos cenários avaliados quando comparado ao PotOcp do ponto de vista do tráfego interno de pacotes HTTP. Entretanto, o desempenho aparentemente melhor do critério Pot está condicionado ao alto percentual de descarte de pacotes handoff das categorias de cobertura inferiores. Desta forma, caso o principal objetivo seja priorizar os tráfegos internos das células HSDPA o critério Pot é mais adequado para atender a este requisito. Caso contrário, se o tráfego interno e em handoff possuírem o mesmo grau de importância para a operadora, o critério de aceitação PotOcp proverá o melhor atendimento a ambos os tráfegos.

Os resultados também demonstraram que o escalonador de dados proposto Pr/PF assegurou a QoS dos usuários com altas prioridades e conseqüentemente apresentou a menor degradação destes quando se aumentou a carga de tráfego handoff no sistema. Entretanto, quando considerada a igualdade na distribuição de recursos do sistema HSDPA, o escalonador PF garantiu não somente o atendimento homogêneo a todos os usuários, mas também a QoS dos usuários de baixa prioridade. Desta maneira, as operadoras que optarem pela diferenciação de serviços devem utilizar o escalonador Pr/PF. Entretanto, caso o foco seja a melhor distribuição de recursos do sistema HSDPA, o escalonador PF será a melhor escolha.

\section{REFERÊNCIAS}

[1] 3GPP Release'5, High Speed Downlink Packet Access (HSDPA); Overall Description. (3GPP TS 25.308 version 5.4.0), 2004.

[2] H. Holma e A. Toskala, Radio Access For Third Generation Mobile Communications. John Wiley, 2000.

[3] Nortel, HSDPA and beyond. White Paper, (NN110820-012805), 2005.

[4] M. Dramitinos, G. Stamoulis e C. Courcoubetis, Auction-based Resource Allocation in UMTS High Speed Downlink Packet Access (HSDPA). Next Generation Internet Networks, pp. 434- 441, Abril 2005.

[5] 3GPP TR 25.896, Feasibility Study for Enhanced Uplink for UTRA FDD (Release 6), v6.0.0.

[6] 3GPP2 WG5 Evaluation Ad Hoc, 1xEV-DV Evaluation Methodology Addendum (V6), Julho 2001.

[7] A. Jalali, R. Padovani, R. Pankaj, Data Throughput of CDMA-HDR a High Efficiency-High Data Rate Personal Communication Wireless System. Vehicular Technology Conference, v. 3, pp. 1854-1858, 2000.

[8] 3GPP 3G TR25.848, Physical layer aspects of UTRA high speed downlink packet access (Release 4). Março 2001.

[9] S. Tekinary e B. Jabbari, A Measurement Based Prioritization Scheme for Handovers in Cellular and Micro-Cellular Networks. IEEE J. Select Areas Commun., v. 10, pp. 1343-1350, Outubro 1992.

[10] H. Holma e A. Toskala, Wcdma for Umts, John Wiley \& Sons, 2002.

[11] H. Nguyen e I. Sasase, Downlink Queuing Model and Packet Scheduling for Providing Lossless Handoff and QoS in 4G Mobile Networks. IEEE Transactions on Mobile Computing, v. 5, pp. 452- 462, Maio 2006.

[12] T. Lin e P. Lin, Handoff Ordering Using Link Quality Estimator for Multimedia Communications in Wireless Networks. IEEE Globecom, v. 2, pp. 1125-1130, Dezembro 2005.

[13] J. Qian, Y. Yanping, W. Kuang e Z. Guangxin, Handoff strategy analysis by Stackelberg model over HSDPA. International Conference on Wireless Communications, Networking and Mobile Computing, WiCom, pp. 1766-1770, Setembro 2007. 